\title{
Temporal and Spatial Variations of Picoplankton and Nanoplankton and Short-Term Variability Related to Stormy Weather in the Danshui River Estuary in Northern Taiwan
}

\author{
An-Yi Tsai ${ }^{1, *}$, Gwo-Ching Gong ${ }^{1}$, Kuo-Ping Chiang ${ }^{1,2}$, Chien-Fu Chao ${ }^{2}$, \\ Hsing-Kai Liao ${ }^{2}$, and Fuh-Kwo Shiah ${ }^{1,3}$ \\ ${ }^{1}$ Institute of Marine Environmental Chemistry and Ecology, National Taiwan Ocean University, Keelung, Taiwan, ROC \\ ${ }^{2}$ Institute of Environmental Biology and Fishery Science, National Taiwan Ocean University, Keelung, Taiwan, ROC \\ ${ }^{3}$ Research Center for Environmental Changes, Academia Sinica, Taipei, Taiwan, ROC
}

Received 06 April 2010, accepted 15 July 2010

\begin{abstract}
This study examined the seasonal dynamics of the bacteria, Synechococcus spp. and their nanoflagellate grazers in the Danshui River estuary in northern Taiwan and compared the variations in microbes (bacteria, Synechococcus spp. and nanoflagellate) dynamics under different (clear vs. stormy) weather conditions. Temporal variations in chlorophyll $a$ concentrations, bacterial production, bacteria and Synechococcus spp. abundance were related to temperature, with higher values during the warmer seasons. Spatial variations in Synechococcus spp. were related to chlorophyll a concentrations and in bacterial production and abundance related to chlorophyll $a$ concentrations when temperature is above $20^{\circ} \mathrm{C}$ (April, August, and October). Spatial variations in nanoflagellates were related to oscillations in bacterial abundance or production during non-rainy periods. We conclude that heavy freshwater input to the estuary carries a large quantity of riverine bacteria which might disrupt the relationship between bacterial and nanoflagellate abundance during rainfall events.
\end{abstract}

Key words: Danshui River estuary, Synechococcus spp., Bacterial abundance, Nanoflagellate

Citation: Tsai, A. Y., G. C. Gong, K. P. Chiang, C. F. Chao, H. K. Liao, and F. K. Shiah, 2011: Temporal and spatial variations of picoplankton and nanoplankton and short-term variability related to stormy weather in the Danshui River estuary in northern Taiwan. Terr. Atmos. Ocean. Sci., 22, 79-89, doi: 10.3319/TAO.2010.07.15.01(Oc)

\section{INTRODUCTION}

In aquatic environments, phytoplankton derived dissolved organic carbon (DOC) is an important source of energy and material supporting the production of heterotrophic bacteria. Because bacteria can consume $30 \%$ to $60 \%$ of the primary production via DOC, the presence of phytoplankton, therefore, strongly influences bacterial dynamics (Fuhrman and Azam 1982; Cole et al. 1988; Kirchman et al. 1991; White et al. 1991; Gasol et al. 1998; Nagata 2000).

Generally, bacterial abundance and productivity in aquatic environments may be linearly dependent on phytoplankton biomass and productivity (Gasol et al. 1998; Nagata 2000). In many oligotrophic waters, there is a close association between bacterial and phytoplankton production (White et al. 1991; Coffin et al. 1993; Gasol and Duarte

\footnotetext{
* Corresponding author

E-mail: anyipingu@yahoo.com.tw
}

2000; Duarte et al. 2005). In estuarine environments, however, the relationship between bacteria and phytoplankton is not so closely related (Ducklow and Kichman 1983; Gasol et al. 1998; Caroppo 2002; Schultz et al. 2003). Therefore, bacteria may also process carbon derived from the allochthonous organic matter released by estuaries and sediments or introduced by rivers rather than process only carbon produced by phytoplankton in estuarine systems (Malone et al. 1991; Hoch and Kirchman 1993; Hullar et al. 1996; Kelley et al. 1998; Schultz et al. 2003). It is possible that limits in allochthonous organic matter caused by a low discharge of freshwater runoff may affect the relationship between bacterioplankton and phytoplankton. One important question might be whether phytoplankton is a major determinant of abundance and spatial distribution of estuarine bacteria during non-rainy periods, when there is less inflow of inorganic and organic materials from freshwater runoff. 
Picophytoplankton is an essential component of microbial food webs and carbon flow, particularly in warm oligotrophic waters (Kuosa 1991; Agawin et al. 2000; Worden et al. 2004; Uysal 2006). Synechococcus spp. have received much attention in many recent coastal phytoplankton studies (DuRand et al. 2001; Worden et al. 2004; Tsai et al. 2005, 2008; Uysal 2006). Seasonal variation in this neritic picophytoplankton is reported to be greatly influenced by irradiance and water temperature as well as by the increased turbulence, river input, and suspended matter caused by storms for spatial variations (Kuosa 1991; Agawin and Agustí 1997; Agawin et al. 1998; Tsai et al. 2008).

The abundance of nanoflagellates is highly variable. Previous studies have largely been concerned with seasonal variations in this abundance, which has often shown a peak during summer (Sander et al. 1992; Safi and Hall 1997; Tsai et al. 2008). However, some studies have shown that low nanoflagellate abundance in summer coincident with strong stratification in the upper water layer reduces the availability of nutrients (Calbet et al. 2001; Huang et al. 2008). The spatial variation of nanoflagellate abundance is clearly higher in coastal eutrophic environments than in offshore oligotrophic environments (Hwang and Heath 1997; Huang et al. 2008). It has been suggested that temperature, chlorophyll $a$, nutrient concentrations, and prey biomass (bacteria and picophytoplankton) may be the major controlling factors for the spatial distribution of nanoflagellates (Safi and Hall 1997; Huang et al. 2008). Hwang and Heath (1997) found that copepod abundance has an influence on the spatial distribution of HNF. Top-down controls such as grazing are thought to set a limit on nanoflagellates abundance, while nanoflagellates growth rates are thought to be set by bottom-up factors such as nutrients, prey supply, and temperature.

The Danshui River estuary is the largest estuarine system in Taiwan and is formed by the confluence of the Tahan Stream, Hsintien Stream, and Keelung River. This estuary receives a relatively small mean annual river discharge $\left(210 \mathrm{~m}^{3} \mathrm{~s}^{-1}\right)$ compared to other larger estuaries, for example the Columbia River estuary in northwestern United States $\left(6700 \mathrm{~m}^{3} \mathrm{~s}^{-1}\right)$ (Simenstad et al. 1990) and Elbe Estuary in Germany $\left(700 \mathrm{~m}^{3} \mathrm{~s}^{-1}\right)$ (Ploug et al. 2002). Thus, in waters receiving little allochthonous organic matter as in Danshui River estuary, we hypothesized that most of the dissolved organic matter to support bacteria growth is from phytoplankton. By examining the relationships among the members of microbial loop- Chl $a$, bacteria, and nanoflagellate, we may better understand the transfer of energy in this marine ecosystem. Therefore, in this study, we investigated the distribution of both picoplankton (bacteria and Synechococcus spp.) and nanoflagellates at different water depths in the Danshui River estuary and studied the possible relationships between these distributional patterns and the inshoreoffshore physical, chemical, and biological gradients. Fur- thermore, we speculate that storms could lead to dramatic reduction in phytoplankton production, which would in turn influence bacterial growth and subsequent changes at higher consumer levels (i.e., nanoflagellate) and trophic transfer. In order to test this hypothesis, we also collected a sample during a rainy period and a week after the rain ended.

\section{MATERIAL AND METHODS}

\subsection{Sampling}

This study had eleven sampling stations (Fig. 1). Nine (stations $1-6$ and 8 -10) were located at three transects of the estuary over progressively greater depths of water $(10,30$ and $50 \mathrm{~m})$. Two additional stations (stations 7 and 11) were located in deep water $(70 \mathrm{~m})$. Complete plankton samples were collected during the four cruises on board the R/V Ocean Researcher II (April, August, October 2007 and January 2008). Two additional samplings were performed during and after a short period of stormy weather, 7 and 15 June 2007, respectively. Seawater was collected using a SeaBird CTD-General Oceanic Rosette assembly with $20 \mathrm{~L}$ Go-Flo bottles at $2 \mathrm{~m}$ depths. Temperature, salinity, and transmission (TM\%) profiles were recorded through the water column (SeaBird CTD-General Oceanic Rosette). A custom-made flow injection analyzer with a detection limit of $0.15 \mu \mathrm{M}$ was used for nitrate analysis (Gong et al. 1995). Chl $a$ was collected by the filtration $(25 \mathrm{~mm} \mathrm{GF} / \mathrm{F})$ method and then measured with an in vitro fluorometer (Turner Design 10-AU-005) in triplicate using 90\% acetone extracts as described in Parsons et al. (1984). Rainfall data were obtained from a local meteorological station.

Bacterial production was estimated by ${ }^{3} \mathrm{H}$-thymidine incorporation (Fuhrman and Azam 1982) with a conversion factor of $1.18 \times 10^{18}$ cells mol thymidine ${ }^{-1}$ (Cho and Azam 1988). Triplicate aliquots of water samples (30 to $40 \mathrm{~mL}$ ) were incubated with ${ }^{3} \mathrm{H}$-[methyl]-thymidine (S.A., 6.7 $\mathrm{Ci} \mathrm{m} \mathrm{mol}{ }^{-1}$; final conc., $20 \mathrm{nM}$ ) in clean polycarbonate test tubes at in situ temperature in the dark for $0.5 \mathrm{~h}$. Reactions were stopped by adding formaldehyde (final conc., $1 \%)$. The fixed samples, including time zero controls, were filtered through $0.2 \mu \mathrm{m}$ cellulose nitrate filters. These filters were then rinsed sequentially 3 times each with ice cold 5\% trichloroacetic acid and ice cold $80 \%$ ethyl alcohol. A scintillation cocktail ( $6 \mathrm{ml}$; Ultima Gold, Packard) was added after dried filters were dissolved completely in ethyl acetate $(0.5 \mathrm{~mL})$. Radioactivity was determined by liquid scintillation (Packard 1600).

\subsection{Plankton Abundance}

\subsubsection{Flow Cytometric Analysis of Picoplankton}

The samples $(2 \mathrm{~mL})$ for flow cytometry analysis were fixed with $40 \mu \mathrm{L}$ paraformaldehyde ( $0.2 \%$ final conc.), quickly frozen in liquid nitrogen, and stored in a freezer at 


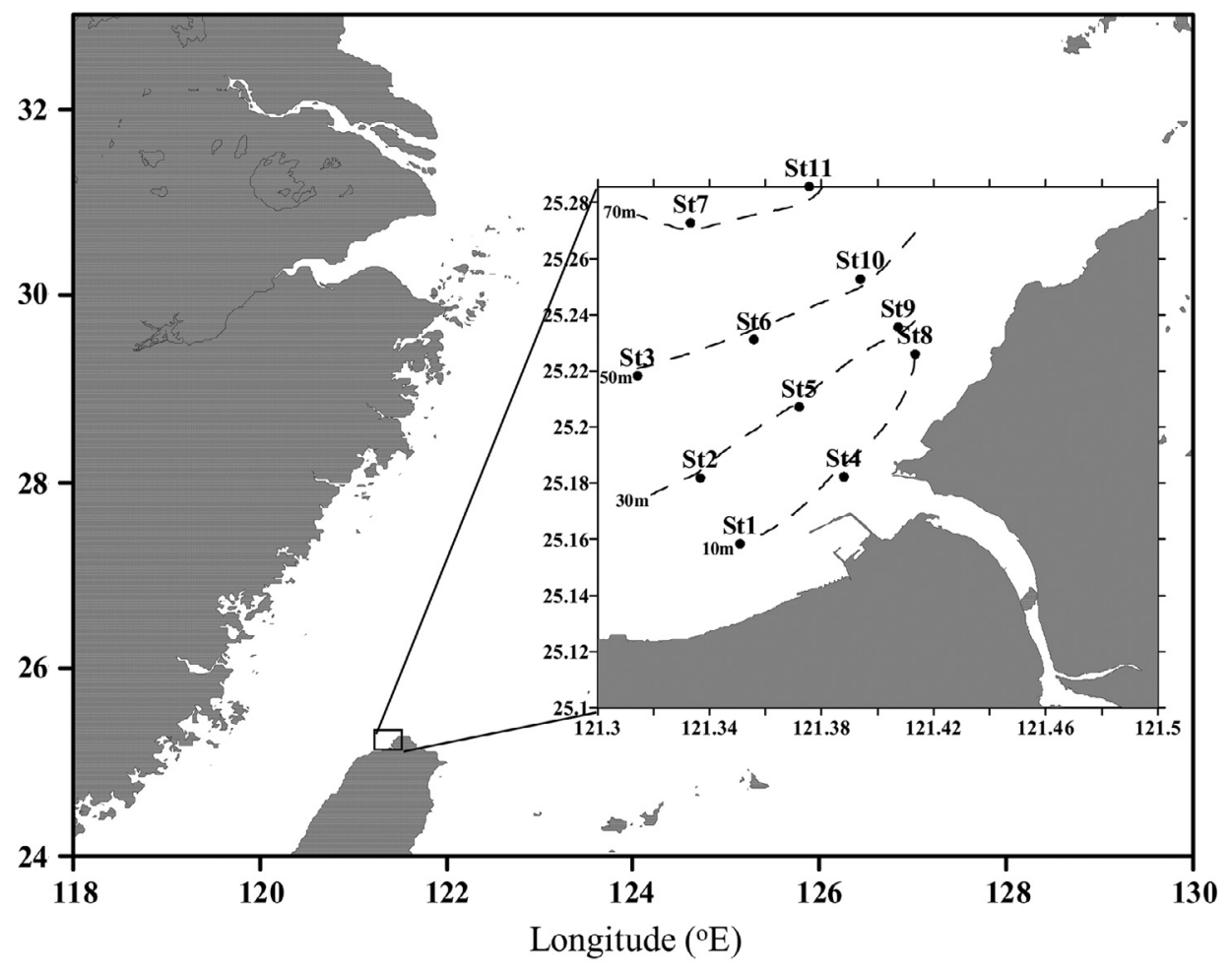

Fig. 1. Map of the sampling stations.

$-75^{\circ} \mathrm{C}$ for later analysis. Abundances of picoplankton (bacteria and Synechococcus spp.) were measured using a Becton Dickinson LSR 6 Flow Cytometer. The samples were acquired on a low rate setting for $2 \mathrm{~min}$. Synechococcus spp. were distinguished according to their position in plots of orange (FL2) and red (FL3) fluorescence. SYBR Green I (Molecular Probes) was used as the nucleic acid stain (Marie et al. 1997) to identify bacteria in plots of FL3 vs. green (FL1) fluorescence. Internal calibration beads $(1 \mu \mathrm{m}$ yellow-green fluorescence beads) were added as a standard.

\subsubsection{Epifluorescence Microscopic Analysis of Nano- plankton}

Samples for the measurement of nanoplankton quantities were fixed immediately by adding cacodylate-buffered glutaraldehyde. A Millipore filter $(0.45 \mu \mathrm{m})$ was used to obtain uniform distribution of cells with low pressure $(<100 \mathrm{~mm} \mathrm{Hg})$. Pigmented- and non-pigmented nanoflagellates were determined from samples $(20 \mathrm{~mL})$ filtered onto black Nuclepore filters $(0.8 \mu \mathrm{m})$. Cells left on the filter membranes were stained with DAPI (4'6-diamidino-2phenylindole) at a final concentration of $1 \mu \mathrm{g} \mathrm{mL}^{-1}$ (Porter and Feig 1980), and examined by epifluorescence microscope $(1000 \times$, Nikon Optiphot-2). Non-pigmented nanoflagellates were identified by their blue fluorescence under UV illumination, and pigmented nanoflagellates were identified by their orange and red autofluorescence under blue light. To obtain reliable estimates of abundance, at least 100 nanoflagellates were counted per sample.

\subsection{Statistical Analysis}

A correlation analysis with a significance level of 5\% was undertaken between physical (temperature, light transmission), chemical (salinity, $\mathrm{NO}_{3}$ ) and biological variables (Chl $a$, bacteria, Synechococcus spp., bacterial production and nanoflagellate). All statistical operations were performed using Statistica (version 7.0).

\section{RESULTS}

\subsection{Temporal and Spatial Variations of Temperature and Salinity}

Precipitation accumulation values were recorded from the Central Weather Bureau of Taiwan during the three-day period prior to each sampling day (Fig. 2). The weather was stormy on 7 June 2007 (Fig. 2). During clear weather, temperature varied less than $0.5^{\circ} \mathrm{C}$ among stations (Fig. 3), while average surface water temperatures showed marked seasonality, ranging from an average of $18.4^{\circ} \mathrm{C}$ in January (Fig. 3d) to $27.9^{\circ} \mathrm{C}$ in August (Fig. 3b). The salinity conditions at Station 4 were clearly influenced by river flow. During clear weather, surface salinity at this station was between 29.9 and 33.9 psu (Fig. 3), dipping to $<32$ psu in August and October 2007 (Figs. 3b, c). 
In times of storms, heavy rains caused marked variation in temperature and salinity at different stations. For example, on 7 June 2007 temperature ranged from 25.3 to $28^{\circ} \mathrm{C}$ and salinity from 7.5 to 33.8 psu (Fig. 3e). However, one week after the storm (15 June 2007), surface salinity gradients did not vary significantly, except for one low value of $<30$ psu at St. 2 (Fig. 3f).

\subsection{Temporal and Spatial Variations of Hydrography}

Seasonally, average $\mathrm{NO}_{3}$ concentrations ranged from a low of $2.0 \mu \mathrm{M}$ in October to a high of $5.7 \mu \mathrm{M}$ in January (Fig. 4a). The highest mean was near the estuarine mouth at St. 4 (10 m deep) $(3.1-6.9 \mu \mathrm{M})$. Values decreased with increasing water depth, with lowest concentration (0.7 $4.8 \mu \mathrm{M}$ ) occurring at $70 \mathrm{~m}$ (Fig. $4 \mathrm{a}$ ). Mean $\mathrm{NO}_{3}$ concentrations varied spatially during the storm on 7 June, consistently with low concentrations ranging from 5.7 to $7.3 \mu \mathrm{M}$ at depths from 50 to $70 \mathrm{~m}$ at various stations, peaking at $25.7 \mu \mathrm{M}$ at St. 4 (Fig. 4d). One week after the storm, however, we found no clear spatial variations in $\mathrm{NO}_{3}$ concentrations.

Average Chl $a$ concentrations ranged from $0.4 \mathrm{mg} \mathrm{m}^{-3}$ in January to $1.6 \mathrm{mg} \mathrm{m}^{-3}$ in August (Fig. 4b). Spatially, there were no significant difference in $\mathrm{Chl} a$ concentration among the stations sampled at different times of the year except for August (ANOVA, $p>0.05$ ) (Fig. 4b). During the storm, average Chl $a$ concentrations ranged from 0.3 to $1.1 \mathrm{mg} \mathrm{m}^{-3}$ among stations, but no difference with water depths (ANO$V A, p>0.05$ ) (Fig. 4e).

We averaged measurements taken at each station to derive a general pattern of surface water transmission (TM\%) along transects with different water depth. TM (\%) was found to be significantly greater in August $(t$-test, $p<0.05)$ for all sampling water depths except at 10-m depth during non-rainy stable weather, with a mean of $40 \%$ in January 2008 and 62\% in August 2007 (Fig. 4c). Furthermore, there were significant differences in TM (\%) between depths of 10 and $70 \mathrm{~m}(t$-test, $p<0.05)$ (Fig. $4 \mathrm{c})$.

\subsection{Temporal and Spatial Patterns in Picoplankton (Bac- teria and Synechococcus spp.) and Nanoplankton}

Bacterial abundance was significantly higher in April and August $\left(6-8 \times 10^{5}\right.$ and $7-7.5 \times 10^{5}$ cells $\mathrm{mL}^{-1}$, re-

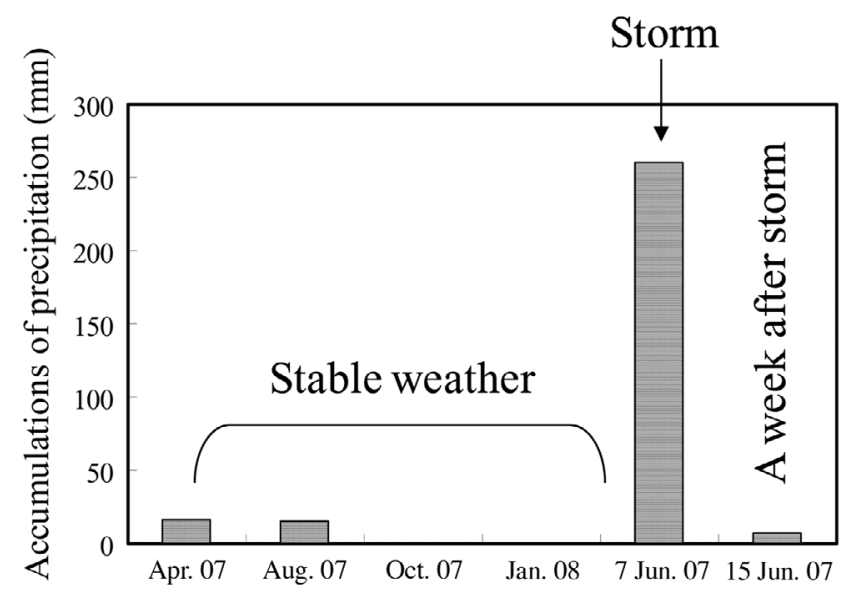

Fig. 2. Precipitation accumulation values were recorded in the threeday period prior to the sampling day.

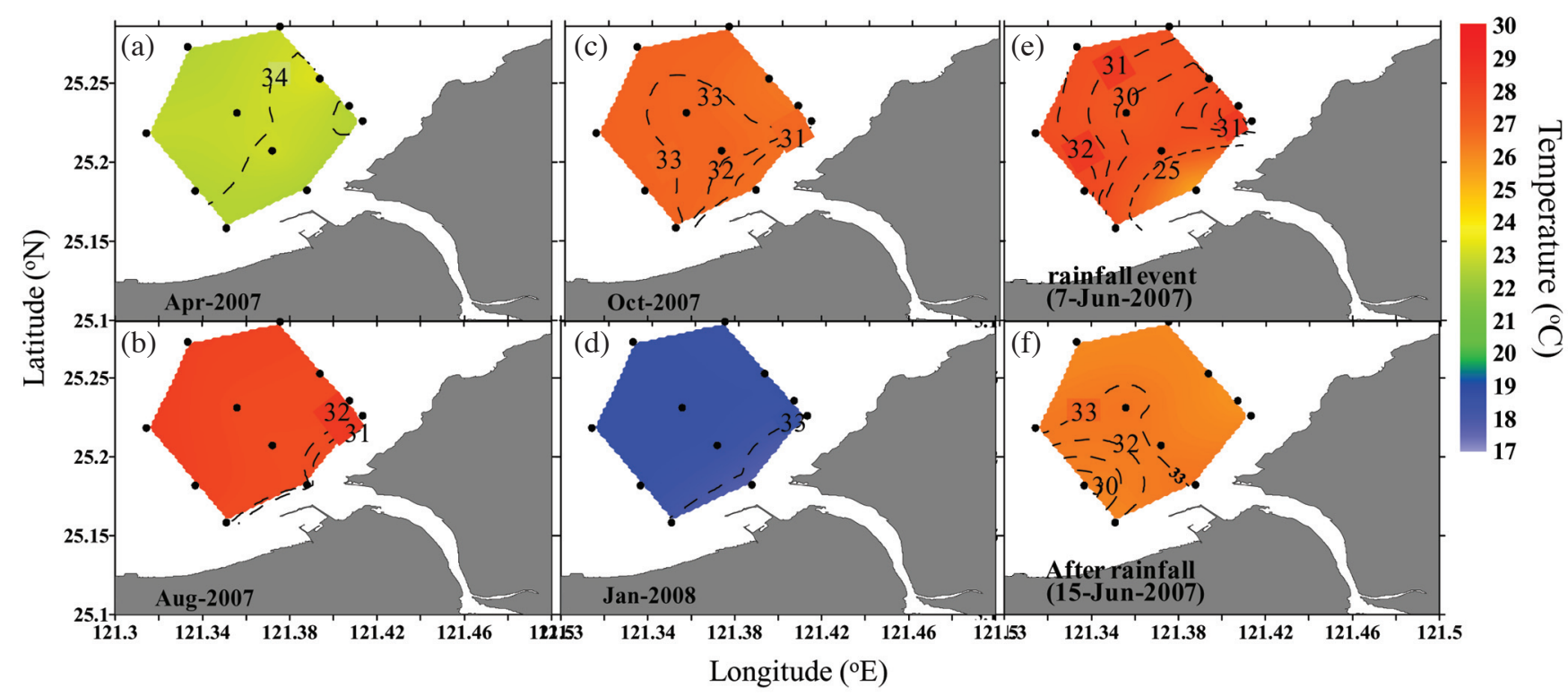

Fig. 3. Non-rainy weather, storm weather and after a week of storm distribution of surface temperature $\left({ }^{\circ} \mathrm{C}\right)$ and salinity (dashed lines). Samples were collected from four cruises during non-rainy weather: (a) April 2007, (b) August 2007, (c) October 2007, and (d) January 2008; Storm weather: (e) 7 June 2007 and after a week of storm: (f) 15 June 2007. 

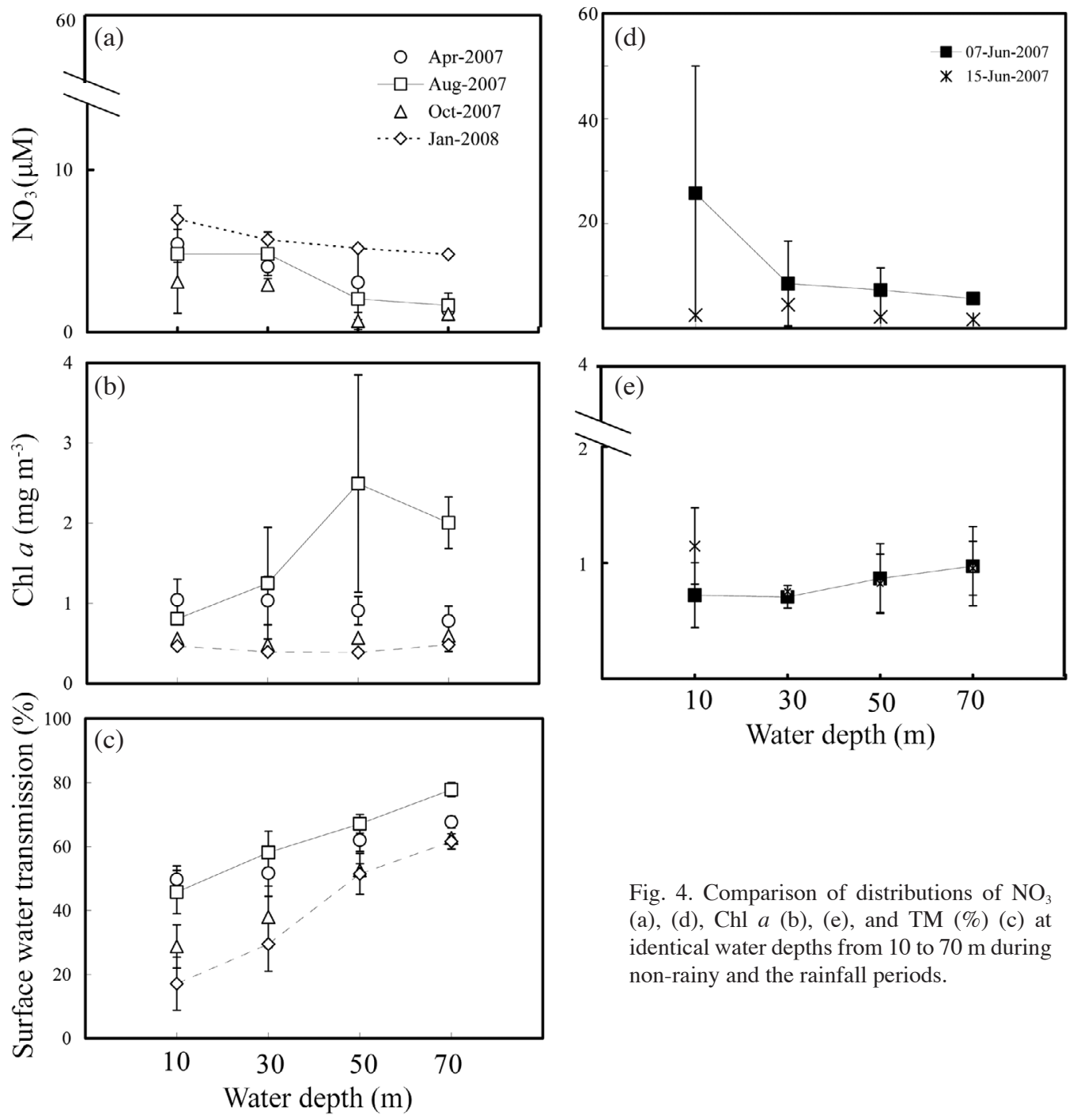

Fig. 4. Comparison of distributions of $\mathrm{NO}_{3}$ (a), (d), Chl $a$ (b), (e), and TM (\%) (c) at identical water depths from 10 to $70 \mathrm{~m}$ during non-rainy and the rainfall periods.

spectively) than in January $\left(4-4.7 \times 10^{5}\right.$ cells $\left.\mathrm{mL}^{-1}\right)(t$-test, $p<0.05$ ) (Fig. 5a) during the non-rainy weather. However, bacterial abundance was significantly higher $(10-16 \times$ $10^{5}$ cells $\left.\mathrm{mL}^{-1}\right)$ in storm on 7 June 2007 than other samples $(t$-test, $p<0.05)$ (Fig. 5d).

Synechococcus spp. values were higher in August than in other months ( $t$-test, $p<0.05$ ) (Fig. $5 b)$. August values ranged between 1.2 and $3.5 \times 10^{4}$ cells $\mathrm{mL}^{-1}$ (mean of $2.8 \times$ $10^{4}$ cells $\left.\mathrm{mL}^{-1}\right)$. We found significant differences between offshore (water $70 \mathrm{~m}$ depth) and inshore (water $10-30 \mathrm{~m}$ depth) distribution of Synechococcus spp. in our August and October samples ( $t$-test, $p<0.05$ ) (Fig. $5 b)$. During the 7 June storm, abundances $\left(0.7\right.$ to $1.5 \times 10^{5}$ cells $\left.\mathrm{mL}^{-1}\right)$ were slightly lower than in August, but were not different from the stations (ANOVA, $p>0.05$ ) (Fig. 5e).

Figure $5 \mathrm{c}$ shows the spatial and temporal variations in concentrations of total nanoflagellates in clear weather at the study stations. At depths of $10 \mathrm{~m}$, maximum abundance $\left(>2 \times 10^{3}\right.$ cells $\left.\mathrm{mL}^{-1}\right)$ was observed in April 2007, while at other stations they were about $1 \times 10^{3}$ cells $\mathrm{mL}^{-1}$ (Fig. $5 \mathrm{c}$ ). However, at depths of 50 and $70 \mathrm{~m}$, concentrations of nanoflagellates were higher in August and October than in other months (Fig. 5c) ( $t$-test, $p<0.05)$. However, in stormy weather, there was a general trend of increase in total nanoflagellate abundance with increase of water depth from 10 to $70 \mathrm{~m}$ (Fig. 5f). Regardless of the weather conditions, pigmented nanoflagellates dominated the nanoflagellate community $(57 \%-88 \%)$ (data not shown) in all samples.

\subsection{Bacterial Production}

Figure 6 gives the bacterial production rate of all stations. Bacterial production rates were significantly higher (ANOVA, $p<0.05)$ in August $\left(2.5-16.5 \mathrm{mgC} \mathrm{m}^{-3} \mathrm{~d}^{-1}\right)$ than other months $\left(1-11.5 \mathrm{mgC} \mathrm{m}^{-3} \mathrm{~d}^{-1}\right)$ (Fig. 6). For further analysis of the relation between bacterial production rates and bacterial abundance, we found that in non-rainy weather, except in August, the greater the bacterial abundance, 

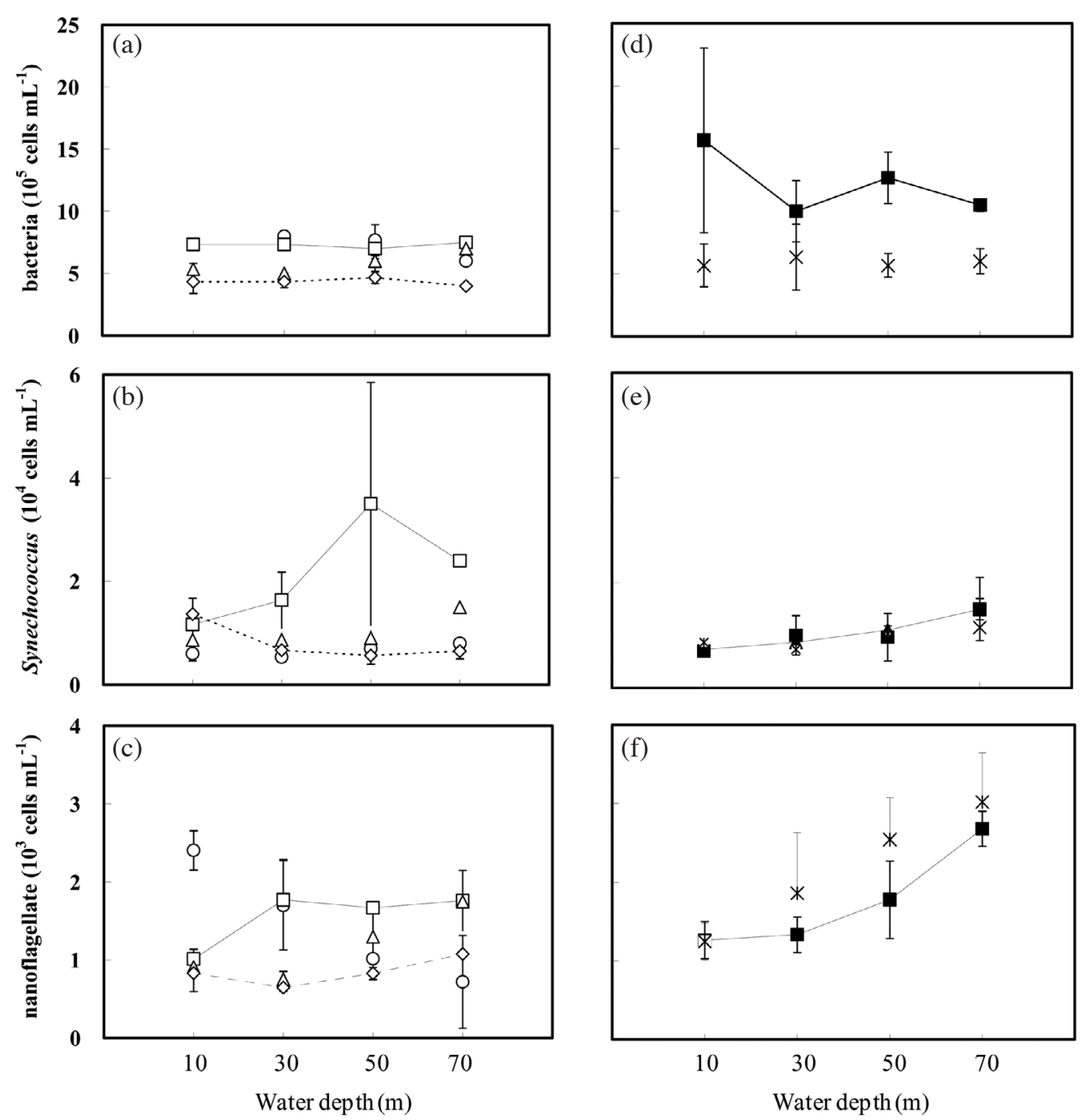

Fig. 5. Comparison of distributions of bacteria (a) (d), Synechococcus spp. (b) (e), and total nanoflagellates (\%) (c) (f) along water depths from 10 to $70 \mathrm{~m}$ during non-rainy and the rainfall periods. Marks as in Fig. 4.

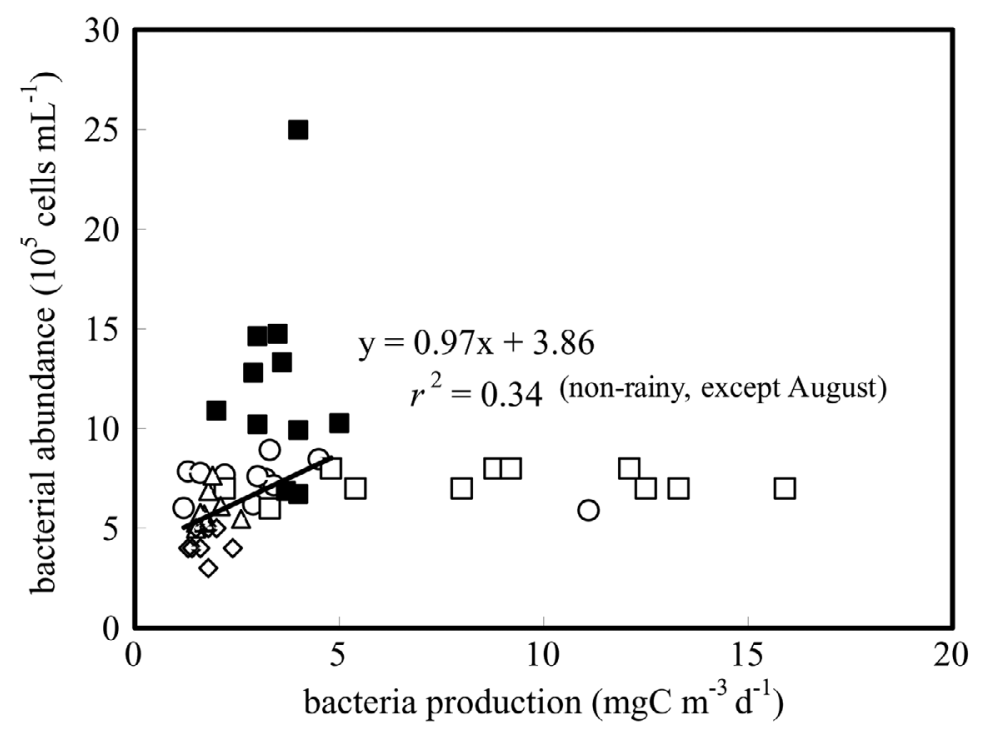

Fig. 6. Relationship between bacterial production and bacterial abundance. Marks as in Fig. 4. 
the greater the bacterial production rate $\left(<5 \mathrm{mgC} \mathrm{m}^{-3} \mathrm{~d}^{-1}\right)$. We did not have data of the bacterial production rate for 15 June; however, we found no significant relationship between bacterial production rate and bacterial abundance during the 7 June storm event and bacterial production rates were low ( $\left.<5 \mathrm{mgC} \mathrm{m}^{-3} \mathrm{~d}^{-1}\right)$ (Fig. 6).

\section{DISCUSSION AND CONCLUSION}

\subsection{Temporal and Spatial Variations of $\mathrm{Chl} a$}

Fluctuations in Chl $a$ concentrations were related to temperature (Table 1). Moreover, as for spatial changes in Chl $a$ concentrations, the result showed a negative correlation with salinity in April (Table 2). We found no correlations between Chl $a$ concentrations and any environmental parameter [i.e., turbidity (TM\%), salinity, nutrient] in other months. Controls on spatial dynamics of phytoplankton in the estuary are more complex than in oligotrophic waters. Generally, growth rates of phytoplankton are controlled by light intensity, temperature, and nutrient concentrations in the euphotic zone. However, photosynthetic studies of the St. Lawrence River transition zone have indicated that the phytoplankton are well adapted to the intermittent exposure to bright light which might occur within the turbid, wellmixed waters (Vincent et al. 1994). Although our samples were all collected during the daytime, we cannot rule out the possibility that $\mathrm{Chl} a$ dynamics are partly related to the photoadaptation, as has been shown elsewhere (Vincent et al.

Table 1. Pearson correlation coefficients for the temporal relationship between microbes (Chl $a$, bacterial, Synechococcus spp., nanoflagellate abundance and bacterial production) and surface water temperature and $\mathrm{Chl} a$ concentrations.

\begin{tabular}{lcc}
\hline & temperature & Chl $\boldsymbol{a}$ \\
\hline Chl $a$ & $0.58 *$ & \\
bacterial abundance & $0.63 *$ & $0.60 *$ \\
Synechococcus spp. abundance & $0.61 *$ & $0.87 * *$ \\
nanoflagellate abundance & & \\
bacterial production & $0.45 *$ & $0.82 * *$ \\
\hline
\end{tabular}

* Correlation is significant at the 0.05 level (2-tailed).

** Correlation is significant at the 0.01 level (2-tailed).

Table 2. Pearson correlation coefficients for the spatial relationship between microbes (Chl $a$, bacterial, Synechococcus spp., nanoflagellate abundance and bacterial production) and surface water salinity, Chl $a$ concentrations, bacterial abundance and production.

\begin{tabular}{|c|c|c|c|c|}
\hline & salinity & Chl $a$ & bacterial abundance & bacterial production \\
\hline Chl $a$ & $-0.85^{* *}$ (Apr.) & & & \\
\hline \multirow[t]{3}{*}{ bacterial abundance } & $-0.81 * *$ (Apr.) & $0.76^{*}$ (Apr.) & & \\
\hline & $-0.95 * *$ (storm $)$ & 0.60* (Aug.) & & \\
\hline & & $0.85^{* *}$ (Oct.) & & \\
\hline \multirow[t]{6}{*}{ Synechococcus spp.abundance } & $0.78 *($ Apr.) & $0.92 * *$ (Apr.) & & \\
\hline & $0.55^{*}$ (Oct.) & 0.93** (Aug.) & & \\
\hline & $0.70 *(\underline{\text { storm }})$ & $0.65 *$ (Oct.) & & \\
\hline & $0.90 * *$ (after storm) & $0.52 *$ (Jan.) & & \\
\hline & & $0.66^{*}$ (storm) & & \\
\hline & & $0.56 *$ (after storm) & & \\
\hline \multirow[t]{3}{*}{ nanoflagellate abundance } & & & $0.45 *$ (Apr.) & $0.70 *$ (Apr.) \\
\hline & & & $0.64 *$ (Oct.) & $0.57 *$ (Oct.) \\
\hline & & & & $0.67 *(J a n)$ \\
\hline \multirow[t]{3}{*}{ bacterial production } & $-0.47 *$ (Apr.) & $0.60 *$ (Apr.) & $0.55^{*}$ (Apr.) & \\
\hline & $-0.90 * *$ (Aug.) & 0.60* (Aug.) & $0.62 *$ (Oct.) & \\
\hline & & $0.78 *$ (Oct.) & & \\
\hline
\end{tabular}

\footnotetext{
* Correlation is significant at the 0.05 level (2-tailed).
}

** Correlation is significant at the 0.01 level (2-tailed). 
1994). Other factors, such as loss due to grazing, may also have influenced this spatial pattern of Chl $a$. The density of macrozooplankton and microzooplankton are known to be high in estuaries (Lovejoy et al. 1993; Vincent et al. 1994; Calbet 2001; Winkler et al. 2003), and thus a drop in Chl $a$ concentration in these regions (water depth at $10 \mathrm{~m}$ ) may result from increased grazing. On the other hand, storms can cause a decrease in situ light intensity and an increase in suspended matter from terrestrial runoff or turbulence, which can result in lower Chl $a$ concentrations as in our study $\left(<1 \mathrm{mg} \mathrm{m}^{-3}\right)$ (Fig. 4e).

\subsection{Temporal and Spatial Variations of Synechococcus Spp.}

Numerous seasonal studies have shown that an abundance of Synechococcus spp. is the greatest during warmer months (Ning et al. 2000; Tsai et al. 2005, 2008). The influence of irradiance and water temperature on the seasonal distributions of abundance and biomass of Synechococcus spp. has been established (Kuosa 1991; Chang et al. 1996; Agawin et al. 1998; Tsai et al. 2008). Although the relationship between temperature and abundance may be confounded by an autocorrelation between light and temperature, we suggest that temperature, including its relative variability, is a major physical factor affecting the numerical response of Synechococcus spp. (Table 1).

We also observed peaks of Synechococcus spp. abundance in summer (August) (Fig. 5b), which may be explained by transient imbalances between growth rates and grazing rates of Synechococcus spp. outpacing nanoflagellate grazing rate and the increased food concentration for nanoflagellates (i.e., increased bacterial production in summer) (Fig. 6). This could result in a release in grazing pressure on Synechococcus spp. because, as Landry et al. (1984) have suggested, the threshold of Synechococcus spp. abundance corresponds significantly to grazing by nanoflagellates at $6 \times 10^{4}$ cells $\mathrm{mL}^{-1}$. It is also evident from Fig. 6 that bacterial abundance did not increase along with increasing bacterial production rate in August, suggesting that the upward transfer of bacterial organic matter in the food web occurred mainly during the warm season (August) in this study.

Synechococcus spp. have not been measured in the Danshui River estuary. While the importance of Synechococcus spp. and other picophytoplankton is well documented in the open oceans (Fogg 1995), their importance in estuaries is less well studied (Murrell and Lores 2004). Murrell and Lores (2004) reported that Synechococcus spp. in Pensacola Bay in general represented $43 \%$ of the total chlorophyll, but up to over $90 \%$ in summer. In other estuaries, their contribution to the total chlorophyll appears to be much smaller. For example, in the York River estuary, picophytoplankton comprises $7 \%$ of chlorophyll over an annual cycle, peak- ing at $14 \%$ during summer (Ray et al. 1989). In the present study, we found spatial variations in Synechococcus spp. to be related to chlorophyll $a$ concentrations (Table 2), which suggests that Synechococcus spp. dominate the chlorophyll biomass in this estuary. According to literature, contribution of picophytoplankton to bulk chlorophyll is only dominant in oligotrophic environments where chlorophyll levels range from 0.5 to $1 \mu \mathrm{g} \mathrm{L}^{-1}$, and their contribution diminishes with increases in trophic state. While this pattern may hold for temperate estuaries, Danshui River estuary and similar subtropical systems such as Pensacola Bay (Murrell and Lores 2004) do not fit this pattern.

\subsection{Bacterial Variations}

Previous studies have reported temperature to strongly affect estuarine bacterial abundance and growth (Shiah and Ducklow 1994; Schultz et al. 2003; Tsai et al. 2008); nevertheless, Ochs et al. (1995) found and later confirmed by Shiah and Ducklow (1994) that bacterial growth rates were unrelated to temperature above $14^{\circ} \mathrm{C}$. Their findings suggest that temperature might control growth activity during the colder months. Growth in the warmer seasons seems to be controlled by factors such as substrate supply or availability of nutrients (Keil and Kirchman 1991). Our results showed that spatial variations in bacterial production and abundance were related to chlorophyll $a$ concentrations (Table 2) when temperature is above $20^{\circ} \mathrm{C}$ (April, August, and October). Our result agrees with those of previous studies reporting temperature not to be an important determinant of bacterial production rates during the warmer seasons (Shiah and Ducklow 1994; Ochs et al. 1995). In addition, during the warmer August season, we found the minor changes in bacterial abundance to be accompanied by high bacterial production (5 - $15 \mathrm{mgC} \mathrm{m}^{-3} \mathrm{~d}^{-1}$ ) (Fig. 6), suggesting that predation on bacteria exerted more influence on bacteria dynamics than resource supply during the warmer August season (Boissonneault-Cellineri et al. 2001; Hahn et al. 2001; Schultz et al. 2003).

There appeared to be different factors controlling bacterial production and abundance under stable, clear weather and stormy weather. Primary production appears to have provided most of the carbon needed for bacterial production in stable, clear weather, bacterial production and abundance were all related to Chl $a$ concentrations (Table 2). We also found that bacterial abundance was significantly higher $\left(10-16 \times 10^{5}\right.$ cells $\left.\mathrm{mL}^{-1}\right)$ during the storm on 7 June than during the non-rainy warm periods in August (Fig. $5 d)$ and that changes in bacterial abundance were mostly closely related to changes in salinity $(p<0.05)$ (Table 2 ). Previous studies have suggested that the concentration of nutrients and dissolved substrates along the salinity gradient may be important in the control of bacterial growth (Kelley et al. 1998; Schultz et al. 2003); however, in our study 
there was no evidence to indicate that bacterial production was related to changes in salinity of the storm on 7 June (Table 2). Furthermore, in the Danshui River estuary during periods of heavy rainfall, the average value of bacterial production was too low (about $3-5 \mathrm{mgC} \mathrm{m}^{-3} \mathrm{~d}^{-1}$ ) (Fig. 6) to significantly raise bacterial abundance $\left(25 \times 10^{5}\right.$ cells $\left.\mathrm{mL}^{-1}\right)$. On the other hand, we estimated bacterial cell carbon in our study to be $25 \mathrm{fg} \mathrm{C}$ cell $^{-1}$, a value characteristic of bacteria in nutrient-rich waters (Bell 1993). Based on this value, we estimated that during the stormy event on 7 June bacterial growth rate was about $0.12 \mathrm{~d}^{-1}(\mathrm{BP} / \mathrm{BB})$. This growth rate was much lower than that reported by Tsai et al. (2008) in their study of the western subtropical coast of the Pacific. Based on our observations, it is possible that the increase in bacterial abundance during the stormy event on 7 June was not as much the result of increased growth as that of heavy freshwater input carrying a large quantity of riverine bacteria into the estuary.

Nanoflagellates provide an important link with the transfer of carbon within the microbial food-web; therefore, it is important to understand the factors which affect their abundance in order to develop an understanding of the flux of carbon in this estuary. Fifty-seven to eighty-eight percent of the nanoflagellates in our samples were pigmented, a percentage similar to that $(>50 \%)$ reported by Tsai et al. (2007) for the western subtropical coast of the Pacific. Previous studies of pigmented nanoflagellates have highlighted the potential ecological significance of these organisms in the aquatic environment and have found evidence that many pigmented nanoflagellates are capable of phagotrophy (Bird and Kalff 1986; Caron et al. 1990). In the present study, because we assumed that pigmented nanoflagellates were capable of phagotrophy, we correlated data over all surface data from separate sampling stations, between bacteria abundance/production and total nanoflagellate abundance in our study site. As shown in Table 2, we founded a correlation between bacteria production and nanoflagellate abundance in non-rainy weather (April, October, and January) (Table 2). We suggest that spatial variations of nanoflagellates are related to oscillations of bacterial abundance or production in the non-rainy periods. Moreover, the correlations between nanoflagellates and bacterial abundance may be lost during storms (Table 2), which might explain the disruption in the relationship between bacterial and nanoflagellate abundance to be caused by the sudden influx of riverine bacteria.

In conclusion, our study shows that spatial variations in Synechococcus spp. are related to chlorophyll a concentrations in the Danshui River estuary. Moreover, spatial variations in bacterial production and abundance are related to chlorophyll $a$ concentrations when temperature is above $20^{\circ} \mathrm{C}$ (April, August, and October). Spatial variations in nanoflagellates are related to oscillations of bacterial abundance or production in the non-rainy periods. Most impor- tantly, we suggest that heavy freshwater input can carry a large quantity of riverine bacteria into the estuary, possibly explaining how riverine bacteria might have disrupted the relationship between bacterial and nanoflagellate abundance during rainfall events.

Acknowledgements This study was supported by a grant (NSC 96-2621-Z-019-001-MY2 and NSC 96-2621-Z-019002-MY2) from the National Science Council, ROC.

\section{REFERENCES}

Agawin, N. S. R. and S. Agustí, 1997: Abundance, frequency of dividing cells and growth rates of Synechococcus sp. (cyanobacteria) in the stratified Northwest Mediterranean Sea. J. Plankton Res., 19, 1599-1615, doi: 10.1093/plankt/19.11.1599. [Link]

Agawin, N. S. R., C. M. Duarte, and S. Agustí, 1998: Growth and abundance of Synechococcus sp. in a Mediterranean Bay: Seasonality and relationship with temperature. Mar. Ecol. Prog. Ser., 170, 45-53, doi: 10.3354/ meps 170045. [Link]

Agawin, N. S. R., C. M. Duarte, and S. Agustí, 2000: Nutrient and temperature control of the contribution of picoplankton to phytoplankton biomass and production. Limnol. Oceanogr., 45, 591-600.

Bell, R. T., 1993: Estimating growth and productivity of heterotrophic bacteria via incorporation of tritiated thymidine. In: Kemp, P., B. Sherr, E. Sherr, and J. J. Cole (Eds.), Handbok of Methods in Aquatic Microbial Ecology, Lewis Publ., Chelsea, MI, 495-503.

Bird, D. F. and J. Kalff, 1986: Bacterial grazing by planktonic lake algae. Science, 231, 493-495, doi: 10.1126/ science.231.4737.493. [Link]

Boissonneault-Cellineri, K. R., M. Mehta, D. J. Lonsdale, and D. A. Caron, 2001: Microbial food web interactions in two Long Island embayments. Aquat. Microb. Ecol., 26, 139-155. doi: 10.3354/ame026139. [Link]

Calbet, A., 2001: Mesozooplankton grazing impact on primary production: A global comparative analysis in marine ecosystems. Limnol. Oceanogr., 46, 1824-1830, doi: 10.4319/lo.2001.46.7.1824. [Link]

Calbet, A., M. R. Landry, and S. Nunnery, 2001: Bacteriaflagellate interactions in the microbial food web of the oligotrophic subtropical North Pacific. Aquat. Microb. Ecol., 23, 283-292.

Caron, D. A., K. G. Porter, and R. W. Sanders, 1990: Carbon, nitrogen, and phosphorus budgets for the mixotrophic phytoflagellate Poterioochromonas malhamensis (Chrysophyceae) during bacterial ingestion. Limnol. Oceanogr., 35, 433-443.

Caroppo, C., 2002: Variability and interactions of phytoplankton and bacterioplankton in Varano lagoon (Adri- 
atic Sea). J. Plankton Res., 24, 267-273, doi: 10.1093/ plankt/24.3.267. [Link]

Chang, J., C. C. Chung, and G. C. Gong, 1996: Influences of cyclones on chlorophyll $a$ concentration and Synechococcus abundance in a subtropical western Pacific coastal ecosystem. Mar. Ecol. Prog. Ser., 140, 199205, doi: 10.3354/meps 140199. [Link]

Cho, B. C. and F. Azam, 1988: Major role of bacteria in biogeochemical fluxes in the ocean's interior. Nature, 332, 441-443, doi: 10.1038/332441a0. [Link]

Coffin, R. B., J. P. Connolly, and P. S. Harris, 1993: Availability of dissolved organic carbon to bacterioplankton examined by oxygen utilization. Mar. Ecol. Prog. Ser., 101, 9-22.

Cole, J. J., S. Findlay, and M. L. Pace, 1988: Bacterial production in fresh and saltwater ecosystems: A cross-system overview. Mar. Ecol. Prog. Ser., 43, 1-10.

Duarte, C. M., S. Agustí, D. Vaqué, N. S. R. Agawin, J. Felipe, E. O. Casamayor, and J. M. Gasol, 2005: Experimental test of bacteria-phytoplankton coupling in the Southern Ocean. Limnol. Oceanogr., 50, 1844-1854, doi: 10.4319/lo.2005.50.6.1844. [Link]

Ducklow, H. W. and D. L. Kirchman, 1983: Bacterial dynamics and distribution during a spring diatom bloom in the Hudson River plume, USA. J. Plankton Res., 5, 333-355, doi: 10.1093/plankt/5.3.333. [Link]

DuRand, M. D., R. J. Olson, and S. W. Chisholm, 2001: Phytoplankton population dynamics at the Bermuda Atlantic time-series station in the Sargasso Sea. Deep-Sea Res. II, 48, 1983-2003, doi: 10.1016/S09670645(00)00166-1. [Link]

Fogg, G. E., 1995: Some comments on picoplankton and its importance in the pelagic ecosystem. Aquat. Microb. Ecol., 9, 33-39.

Fuhrman, J. A. and F. Azam, 1982: Thymidine incorporation as a measure of heterotrophic bacterioplankton production in marine surface waters: Evaluation and field results. Mar. Biol., 66, 109-120, doi: 10.1007/BF 00397184. [Link]

Gasol, J. M. and C. M. Duarte, 2000: Comparative analyses in aquatic microbial ecology: How far do they go? FEMS Microbiol. Ecol., 31, 99-106, doi: 10.1111/j.15 74-6941.2000.tb00675.x. [Link]

Gasol, J. M., M. D. Doval, J. Pinhassi, J. I. Calderón-Paz, N, Guixa-Boixareu, D. Vaqué, and C. Pedró-Alió, 1998: Diel variations in bacterial heterotrophic activity and growth in the northwestern Mediterranean Sea. Mar. Ecol. Prog. Ser., 164, 107-124, doi: 10.3354/me ps164107. [Link]

Gong, G. C., K. K. Liu, and S. J. Pai, 1995: Prediction of nitrate concentration from two end member mixing in the Southern East China Sea. Cont. Shelf Res., 15, 827 842, doi: 10.1016/0278-4343(94)00039-P. [Link]

Hahn, M. W. and M. G. Hofle, 2001: Grazing of protozoa and its effect on populations of aquatic bacteria. FEMS Microbiol. Ecol., 35, 113-121, doi: 10.1111/j.1574-69 41.2001.tb00794.x. [Link]

Hoch, M. P. and D. L. Kirchman, 1993: Seasonal and interannual variability in bacterial production and biomass in a temperate estuary. Mar. Ecol. Prog. Ser., 98, 283295.

Huang, B., W. Lan, Z. Cao, M. Dai, L. Huang, N. Jiao, and H. Hong, 2008: Spatial and temporal distribution of nanoflagellates in the northern South China Sea. Hydrobiologia, 605, 143-157, doi: 10.1007/s10750-0089330-3. [Link]

Hullar, M. A. J., B. Fry, B. J. Peterson, and R. T. Wright, 1996: Microbial utilization of estuarine dissolved organic carbon: A stable isotope tracer approach tested by mass balance. Appl. Environ. Microbiol., 62, 24892493.

Hwang, S. J. and R. T. Heath, 1997: The distribution of protozoa across a trophic gradient, factors controlling their abundance and importance in the plankton food web. J. Plankton Res., 19, 491-518, doi: 10.1093/ plankt/19.4.491. [Link]

Keil, R. G. and D. L. Kirchman, 1991: Contribution of dissolved free amino acids and ammonium to the nitrogen requirements of heterotrophic bacterioplankton. Mar. Ecol. Prog. Ser., 73, 1-10.

Kelley, C. A., R. B. Coffin, and L. A. Cifuentes, 1998: Stable isotope evidence for alternative bacterial carbon sources in the Gulf of Mexico. Limnol. Oceanogr., 43, 1962-1969.

Kirchman, D. L., Y. Suzuki, C. Garside, and H. W. Ducklow, 1991: High turnover rates of dissolved organic carbon during a spring phytoplankton bloom. Nature, 352, 612-614, doi: 10.1038/352612a0. [Link]

Kuosa, H., 1991: Picoplanktonic algae in the northern Baltic Sea: Seasonal dynamics and flagellate grazing. Mar. Ecol. Prog. Ser., 73, 269-276.

Landry, M. R., L. W. Haas, and V. L. Fagerness, 1984: Dynamics of microbial plankton communities: Experiments in Kaneohe Bay, Hawaii. Mar. Ecol. Prog. Ser., 16, 127-133.

Lovejoy, C., W. F. Vincent, J.-J. Frenett, and J. J. Dodson, 1993: Microbial gradients in a turbid estuary: Application of a new method for protozoan community analysis. Limnol. Oceanogr., 38, 1295-1303.

Malone, T. C., H. W., Ducklow, E. R. Peele, and S. E. Pike, 1991: Picoplankton carbon flux in Chesapeake Bay. Mar. Ecol. Prog. Ser., 78, 11-22.

Marie, D., F. Partensky, S. Jacquet, and D. Vaulot, 1997: Enumeration and cell cycle analysis of natural populations of marine picoplankton by flow cytometry using the nucleic acid stain SYBR Green I. Appl. Environ. Microbiol., 63, 186-193.

Murrell, M. C. and E. M. Lores, 2004: Phytoplankton and 
zooplankton seasonal dynamics in a subtropical estuary: Importance of cyanobacteria. J. Plankton Res., 26, 371-382, doi: 10.1093/plankt/fbh038. [Link]

Nagata, T., 2000: Production mechanisms of dissolved organic matter. In: Kichman, D. L. (Ed.), Microbial Ecology of the Oceans, Wiley-Liss, New-York, 121-152.

Ning, X., J. E. Cloern, and B. E. Cole, 2000: Spatial and temporal variability of picocyanobacteria Synechococcus sp. in San Francisco Bay. Limnol. Oceanogr., 45, 695-702.

Ochs, C. A., J. J. Cole, and G. E. Likens, 1995: Population dynamics of bacterioplankton in an oligotrophic lake. J. Plankton Res., 17, 365-391.

Parsons, T. R., Y. Maita, and C. M. Lalli, 1984: A Manual of Chemical and Biological Methods for Seawater Analysis. Pergamon Press, New York, 173 pp.

Ploug, H., H. Zimmermann-Timm, and B. Schweitzer, 2002: Microbial communities and respiration on aggregates in the Elbe Estuary, Germany. Aquat. Microb. Ecol., 27, 241-248.

Porter, K. G. and Y. S. Feig, 1980: The use of DAPI for identifying and counting aquatic microflora. Limnol. Oceanogr., 25, 943-948.

Ray, R. T., L. W. Haas, and M. E. Sieracki, 1989: Autotrophic picoplankton dynamics in a Chesapeake Bay sub-estuary. Mar. Ecol. Prog. Ser., 52, 273-285.

Safi, K. A. and J. A. Hall, 1997: Factors influencing autotrophic and heterotrophic nanoflagellate abundance in five water masses surrounding New Zealand. N. Z. J. Mar. Freshw. Res., 31, 51-60, doi: 10.1080/00288330.1997.9516744. [Link]

Sanders, R. W., D. A. Caron, and U.-G. Berninger, 1992: Relationships between bacteria and heterotrophic nanoplankton in marine and fresh waters: An inter-ecosystem comparison. Mar. Ecol. Prog. Ser., 86, 1-14.

Schultz, G. E. Jr., E. D. White III, and H. W. Ducklow, 2003: Bacterioplankton dynamics in the York River estuary: Primary influence of temperature and freshwater inputs. Aquat. Microb. Ecol., 30, 135-148, doi: 10.3354/ame030135. [Link]

Shiah, F. K. and H. W. Ducklow, 1994: Temperature regulation of heterotrophic bacterioplankton abundance, production, and specific growth rate in Chesapeake Bay. Limnol. Oceanogr., 39, 1243-1258.

Simenstad, C. A., L. F. Small, C. D. McIntire, D. A. Jay, and C. Sherwood, 1990: Columbia River estuary studies: An introduction to the estuary, a brief history, and prior studies. Prog. Oceanogr., 25, 1-13, doi: 10.1016/00796611(90)90002-J. [Link]

Tsai, A. Y., K. P. Chiang, J. Chang, and G. C. Gong, 2005: Seasonal diel variations of picoplankton and nanoplankton in a subtropical western Pacific coastal ecosystem. Limnol. Oceanogr., 50, 1221-1231.

Tsai, A. Y., K. P. Chiang, Y. F. Chan, Y. C. Lin, and J. Chang, 2007: Pigmented nanoflagellates in the coastal western subtropical Pacific are important grazers on Synechococcus populations. J. Plankton Res., 29, 7177, doi: 10.1093/plankt/fbl058. [Link]

Tsai, A. Y., K. P. Chiang, J. Chang, and G. C. Gong, 2008: Seasonal variations in trophic dynamics of nanoflagellates and picoplankton in coastal waters of the western subtropical Pacific Ocean. Aquat. Microb. Ecol., 51, 263-274, doi: 10.3354/ame01196. [Link]

Uysal, Z., 2006: Vertical distribution of marine Cyanobacteria Synechococcus spp. in the Black, Marmara, Aegean, and eastern Mediterranean seas. Deep-Sea Res. II, 53, 1976-1987, doi: 10.1016/j.dsr2.2006.03.016. [Link]

Vincent, W. F., N. Bertrand, and J.-J. Frenette, 1994: Photoadaptation to intermittent light across the St. Lawrence Estuary freshwater-saltwater transition zone. Mar. Ecol. Prog. Ser., 110, 283-292.

White, P. A., J. Kalff, J. B. Rasmussen, and J. M. Gasol, 1991: The effect of temperature and algal biomass on bacterial production and specific growth rate in freshwater and marine habitats. Microb. Ecol., 21, 99-118, doi: 10.1007/BF02539147. [Link]

Winkler, G., J. J. Dodson, N. Bertrand, D. Thivierge, and W. F. Vincent, 2003: Trophic coupling across the St. Lawrence River estuarine transition zone. Mar. Ecol. Prog. Ser., 251, 59-73, doi: 10.3354/meps251059. [Link]

Worden, A. Z., J. K. Nolan, and B. Palenik, 2004: Assessing the dynamics and ecology of marine picophytoplankton: The importance of the eukaryotic component. Limnol. Oceanogr., 49, 168-179. 